\title{
Phenotypic plasticity of primary thallus in selected Cladonia species (lichenized Ascomycota: Cladoniaceae)
}

\author{
Piotr OsYCZKA ${ }^{1 *} \&$ Kaja RolA ${ }^{2}$ \\ ${ }^{1}$ Department of Polar Research and Documentation, Institute of Botany, Jagiellonian University, Kopernika 27, PL-31-501 \\ Kraków, Poland; e-mail: piotr.osyczka@uj.edu.pl \\ ${ }^{2}$ Department of Plant Taxonomy, Phytogeography \& Herbarium, Institute of Botany, Jagiellonian University, Kopernika \\ 27, PL-31-501 Kraków, Poland; e-mail: kajaskubala@interia.pl
}

\begin{abstract}
The paper presents the results of comprehensive analyses concerning the phenotypic variability of the primary thallus in five chosen Cladonia species in relation to habitat conditions. Morphology and anatomy, as well as the cortex ultrasculpture, of primary squamules were examined in individual specimens from sunny and shady populations of each species. The Mann-Whitney U test and Principal Component Analysis (PCA) revealed several clear correlations between the type of habitat and the organisation of squamules. Significant differences refer mainly to anatomical features, especially to epinecral layer frequency and cortex thickness. On the contrary, examination of the surface ultrasculpture of squamules under SEM did not show any important differences between populations. Regardless of the habitat factors, a full range of cortical surface rugosity in samples from both habitats was noticed, and a high variability often refers to a singular squamule. The results indicate that some features are largely modified by environmental factors and/or depend on the development stage of individual specimens, and examination of these relationships should be the first step towards the evaluation of the taxonomic usefulness of the considered features.
\end{abstract}

Key words: Cladonia cariosa; C. cervicornis subsp. verticillata; C. foliacea; C. phyllophora; C. symphycarpa; lichens; variability

\section{Introduction}

The lichens of the genus Cladonia are known for their dimorphism: firstly, they produce a primary thallus and then variously formed secondary thalli, called podetia. The presence and appearance of these kinds of thalli depend on the particular species and the development stage of the individual specimen. The primary thallus can be conspicuous or evanescent; if present, it usually appears in a form of more or less horizontal squamules, stratified on the transverse section. Podetia are frequently formed; however, there are many species with poorly developed and/or even absent secondary thalli. In this case, species recognition has to be based only on the character of the primary squamules. The taxonomy of the genus is based on morphological features combined with the chemical patterns of the taxa. Because both the morphology and chemistry of many Cladonia groups are highly diverse (e.g., Ahti 2000; Osyczka 2011, 2012; Osyczka \& Skubała 2011), molecular methods are often applied to clarify taxonomic problems (e.g., Stenroos at al. 2002; Dolnik et al. 2010; PinoBodas et al. 2010; Pino-Bodas et al. 2012, see the literature cited herein). Despite the obtainment of molecular data, it is still often difficult to establish whether some features are characteristic only for a particular taxon or depend largely on habitat conditions.

Environmental conditions often modify the organisation and structure of lichen thalli. Some features highly depend on abiotic factors, such as insolation, humidity and thermal fluctuations. The ability of some lichen species to adapt to various microhabitats can be considerable and is frequently manifested by a clear eco-morphological differentiation (Pintado et al. 1997 and literature herein). Noticeable modifications can be observed within one species (see Büdel \& Scheidegger 2008). This concerns, in particular, members of the genus Cladonia, which have high phenotypic plasticity, and their variability is often induced by environmental factors, as well as the developmental stage of individual specimens (Ahti 2000, Osyczka et al. 2007).

Examination of the modificatory variability within Cladonia is crucial for the evaluation of the taxonomic usefulness of particular characteristics. This study concerns five taxa having persistent primary squamules, viz. C. cariosa (Ach.) Spreng., C. cervicornis subsp. verticillata (Hoffm.) Ahti, C. foliacea (Huds.) Willd., C. phyllophora Hoffm., and C. symphycarpa (Flörke) Fr. All of these are confined to rather open and dry situations, such as psammophilous grasslands, sand dunes

* Corresponding author 
Table 1. Collection sites and the main characteristic of habitats for particular species' samples: Site 1 - Cladonia cariosa; Site 2 - C. symphycarpa, C. foliacea; Site $3-C$. phyllophora, C. cervicornis subsp. verticillata.

\begin{tabular}{|c|c|c|c|c|c|c|}
\hline & \multicolumn{2}{|c|}{ Site 1} & \multicolumn{2}{|c|}{ Site 2} & \multicolumn{2}{|c|}{ Site 3} \\
\hline & Habitat 1 & Habitat 2 & Habitat 1 & Habitat 2 & Habitat 1 & Habitat 2 \\
\hline Locality & \multicolumn{2}{|c|}{$\begin{array}{l}\text { Piekary Śląskie town, Wyżyna } \\
\text { Śląska upland } \\
\text { coord.: } 50^{\circ} 21^{\prime} \mathrm{N} ; 18^{\circ} 58^{\prime} \mathrm{E}\end{array}$} & \multicolumn{2}{|c|}{$\begin{array}{l}\text { between Bolesław village } \\
\text { and Bukowno town, Wyżyna } \\
\text { Krakowsko-Czestochowska upland } \\
\text { coord.: } 50^{\circ} 17^{\prime} \mathrm{N} ; 19^{\circ} 28^{\prime} \mathrm{E}\end{array}$} & \multicolumn{2}{|c|}{$\begin{array}{l}\text { Pustynia Błędowska desert, } \\
\text { Wyżyna Śląska upland } \\
\text { coord.: } 50^{\circ} 20^{\prime} \mathrm{N} ; 19^{\circ} 32^{\prime} \mathrm{E}\end{array}$} \\
\hline $\begin{array}{l}\text { Plant } \\
\text { community }\end{array}$ & $\begin{array}{l}\text { xerothermic } \\
\text { grassland from } \\
\text { the class Koele- } \\
\text { rio glaucae- } \\
\text { Corynephoretea } \\
\text { canescentis }\end{array}$ & $\begin{array}{l}\text { edge of artifi- } \\
\text { cially planted } \\
\text { woodland with } \\
\text { Betula pendula } \\
\text { and Robinia } \\
\text { pseudacacia }\end{array}$ & $\begin{array}{l}\text { xerothermic } \\
\text { grassland } \\
\text { from the } \\
\text { class Violetea } \\
\text { calaminariae }\end{array}$ & $\begin{array}{l}\text { edge of artifi- } \\
\text { cially planted } \\
\text { woodland with } \\
\text { Betula pen- } \\
\text { dula and Pinus } \\
\text { sylvestris }\end{array}$ & $\begin{array}{l}\text { grassland } \\
\text { represent- } \\
\text { ing Spergulo- } \\
\text { Corynephoretum } \\
\text { ass. }\end{array}$ & $\begin{array}{l}\text { edge of } \\
\text { Leucobryo- } \\
\text { Pinetum pine } \\
\text { forest }\end{array}$ \\
\hline $\begin{array}{l}\text { General habitat } \\
\text { description }\end{array}$ & $\begin{array}{l}\text { fully exposed } \\
\text { and sunny, dry, } \\
\text { S slope, pH } 7.2- \\
7.9^{*}\end{array}$ & $\begin{array}{l}\text { mostly shady, } \\
\text { mostly dry, NE } \\
\text { slope, } \mathrm{pH} 7.1- \\
7.8^{*}\end{array}$ & $\begin{array}{l}\text { fully exposed } \\
\text { and sunny, dry, } \\
\text { SW slope, pH } \\
7.3-7.8^{*}\end{array}$ & $\begin{array}{l}\text { mostly shady, } \\
\text { mostly dry, W } \\
\text { slope, pH } 7.2- \\
7.4^{*}\end{array}$ & $\begin{array}{l}\text { fully exposed } \\
\text { and sunny, dry, } \\
\text { pH } 5.6-6.3^{*}\end{array}$ & $\begin{array}{l}\text { shady, occasion- } \\
\text { ally moist, } \mathrm{pH} \\
5.2-5.9^{*}\end{array}$ \\
\hline
\end{tabular}

* substrate $\mathrm{pH}$ in $\mathrm{H}_{2} \mathrm{O}$ determined by a Metter-Toledo SevenEasy apparatus.

Table 2. Number of materials (for each of the examined species) and the methods used for particular measurements and observations.

\begin{tabular}{|c|c|c|}
\hline Characteristic & Number of materials & Method \\
\hline Squamule length and width & $\begin{array}{l}25 \text { samples per habitat } \\
3 \text { squamules per sample }\end{array}$ & $\begin{array}{l}\text { examined under a stereoscopic } \\
\text { microscope }\end{array}$ \\
\hline $\begin{array}{l}\text { Overall squamule thickness, cor- } \\
\text { tex thickness, algal layer thickness, } \\
\text { medulla thickness and epinecral layer } \\
\text { thickness }\end{array}$ & $\begin{array}{l}25 \text { samples per habitat } \\
3 \text { transverse sections per sample } \\
3 \text { measurements per transverse } \\
\text { sections }\end{array}$ & \multirow{2}{*}{$\begin{array}{l}\text { transverse sections prepared using a } \\
\text { Leica CM } 1850 \text { UV freezing appara- } \\
\text { tus, stained with a lactophenol blue } \\
\text { solution, examined under a light mi- } \\
\text { croscope }\end{array}$} \\
\hline Epinecral layer frequency & $\begin{array}{l}25 \text { samples per habitat } \\
10 \text { transverse sections per sample }\end{array}$ & \\
\hline Surface ultrasculpture of squamule & $\begin{array}{l}2 \text { samples per habitat } \\
3 \text { squamules per sample }\end{array}$ & $\begin{array}{l}\text { observed by Scanning Electron Mi- } \\
\text { croscopy (SEM) using a HITACHI } \\
\text { S-4700 and NORAN Vantage after } \\
\text { sputter-coating the squamules with a } \\
\text { thin layer of gold }\end{array}$ \\
\hline
\end{tabular}

and the edges of light forests (e.g. Ahti \& Hammer 2002; James 2009; Osyczka \& Skubała 2011). In such places, these lichens frequently appear jointly, forming compact swards, and constitute an important component of plant communities. Based on the selected species, this study is aimed at answering the following question: whether and to what extent environmental factors affect and modify the morphology and anatomical organisation of primary squamules.

\section{Material and methods}

The lichen material was collected in the summer season of 2011 during a phytosociological field study concerning psammophilous grasslands of the upland regions in southern Poland. Two habitats with different conditions were appointed for each species; for the detailed origin of the examined samples, locations of the sites and characteristics of habitats see Table 1. Twenty-five samples of each species were taken from both kinds of habitats. One sample equals a small cluster of primary squamules and podetia, if present. Specimens were chosen randomly and it can be assumed that they generally represent various development stages. The samples were morphologically identified in line with the descriptions given by Ahti (2000), Ahti \& Hammer (2002) and James (2009); nomenclature is given according to MycoBank (2012). The chemical composition of the lichen substances was analysed using TLC, in solvent systems $\mathrm{C}$ and G, following Orange et al. (2001). The lichen samples, regardless of habitat, are chemically homogeneous within the species.

The following morphological/anatomical features were taken into account; abbrev. of characteristics in parentheses: length (SL), width (SW) and thickness (ST) of squamule, thickness of cortex (CT), thickness of algal layer (ALT), thickness of medulla (MT), epinecral layer frequency (ELF) and thickness of epinecral layer (ELT). All these metric fea- 


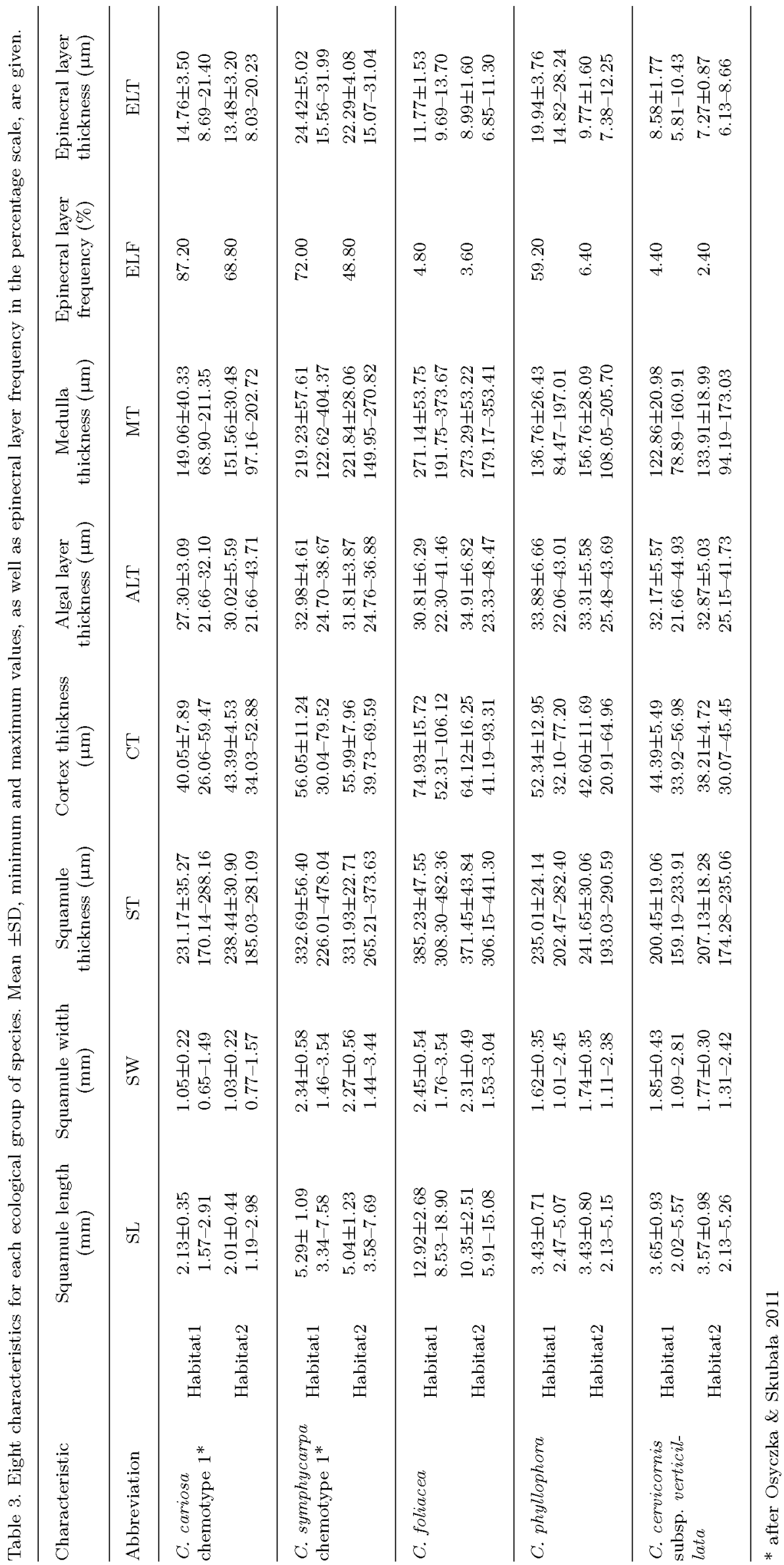


tures were measured by means of Phenix Micro Image Analysis Software after appropriate scaling. Additionally, the ultrasculpture of the surface of the squamule was investigated. The adequate number of materials and the methods used for particular measurements and observations are juxtaposed in Table 2.

Statistical analyses were performed using Statistica 10 (StatSoft Inc.). The normality of distribution features was verified by Lilliefors and Shapiro-Wilk tests; some of the variables proved not to be normally distributed, even after log transformation. Therefore, the obtained morphological and anatomical data were analysed using the MannWhitney $U$ test. Principal Component Analysis (PCA) was performed for all variables and was based on the correlation matrix. This analysis was conducted to determine the features which are most strongly correlated with the first three principal components and to separate the studied habitat groups of particular taxa. As a result, the position of objects (individuals) in a multidimensional space, without any preliminary a priori assumptions, is illustrated. PCA was carried out on two data matrices separately. Matrix $1 \mathrm{com}-$ prises Cladonia cariosa and C. symphycarpa, and matrix 2 includes the other species. The division into two matrices was dictated by the relatedness of the species and was applied in order to achieve clearness of the results and scatter plots.

\section{Results}

Table 3 presents morphological/anatomical measurements and observations for particular species sampled from two different habitats. The results of the MannWhitney U test are provided in Table 4. Some findings should be underlined. Generally, the anatomy of primary squamules depends on habitat factors greater than their morphology. The epinecral layer frequency and cortex thickness significantly differentiate the ecopopulations in the case of as many as three species. The algal layer, medulla and epinecral layer thickness, as well as squamule length, also proved to be variable depending on the habitat, but the significant plasticity of these features has been revealed only for the sin-

Table 4. Results of the Mann-Whitney $\mathrm{U}$ test $(p<0.05): \mathrm{Z}$ and $\mathrm{p}$ values for each characteristic, significant $\mathrm{Z}$ and $\mathrm{p}$ values are given in bold. See Material and methods for abbreviations of characteristics.

\begin{tabular}{|c|c|c|c|c|c|c|c|c|c|c|}
\hline \multirow{2}{*}{ Characteristic } & \multicolumn{2}{|c|}{ C. cariosa } & \multicolumn{2}{|c|}{ C. symphycarpa } & \multicolumn{2}{|c|}{ C. foliacea } & \multicolumn{2}{|c|}{ C. phyllophora } & \multicolumn{2}{|c|}{$\begin{array}{c}\text { C. cervicornis } \\
\text { subsp. verticillata }\end{array}$} \\
\hline & $\mathrm{Z}$ & $\mathrm{p}$ & $\mathrm{Z}$ & $\mathrm{p}$ & $\mathrm{Z}$ & $\mathrm{p}$ & $\mathrm{Z}$ & $\mathrm{p}$ & Z & $\mathrm{p}$ \\
\hline $\mathrm{SL}$ & 0.7762 & 0.4376 & 1.0963 & 0.2730 & 3.0949 & 0.0020 & -0.0194 & 0.9845 & 0.1941 & 0.8461 \\
\hline SW & 0.4368 & 0.6622 & 0.2426 & 0.8083 & 0.6987 & 0.4848 & -1.1160 & 0.2644 & 0.8443 & 0.3985 \\
\hline $\mathrm{ST}$ & -0.6888 & 0.4909 & 0.6403 & 0.5220 & 1.0090 & 0.3130 & -0.8343 & 0.4041 & -1.2225 & 0.2215 \\
\hline $\mathrm{CT}$ & -1.9211 & 0.0547 & -0.0097 & 0.9923 & 2.4836 & 0.0130 & 2.5130 & 0.0120 & 3.5703 & 0.0004 \\
\hline ALT & -1.9116 & 0.0559 & 1.2614 & 0.2072 & -2.3286 & 0.0199 & 0.4172 & 0.6765 & -0.5240 & 0.6003 \\
\hline MT & -0.0388 & 0.9690 & -0.3880 & 0.6980 & -0.1940 & 0.8462 & -2.348 & 0.0189 & -1.6492 & 0.0991 \\
\hline ELF & 4.5099 & 0.0000 & 5.1770 & 0.0000 & 0.2992 & 0.7648 & 6.1591 & 0.0000 & 1.2550 & 0.2095 \\
\hline ELT & 1.2613 & 0.2072 & 1.4358 & 0.1511 & 0.7229 & 0.4698 & 6.1383 & 0.0000 & 1.5116 & 0.1306 \\
\hline
\end{tabular}

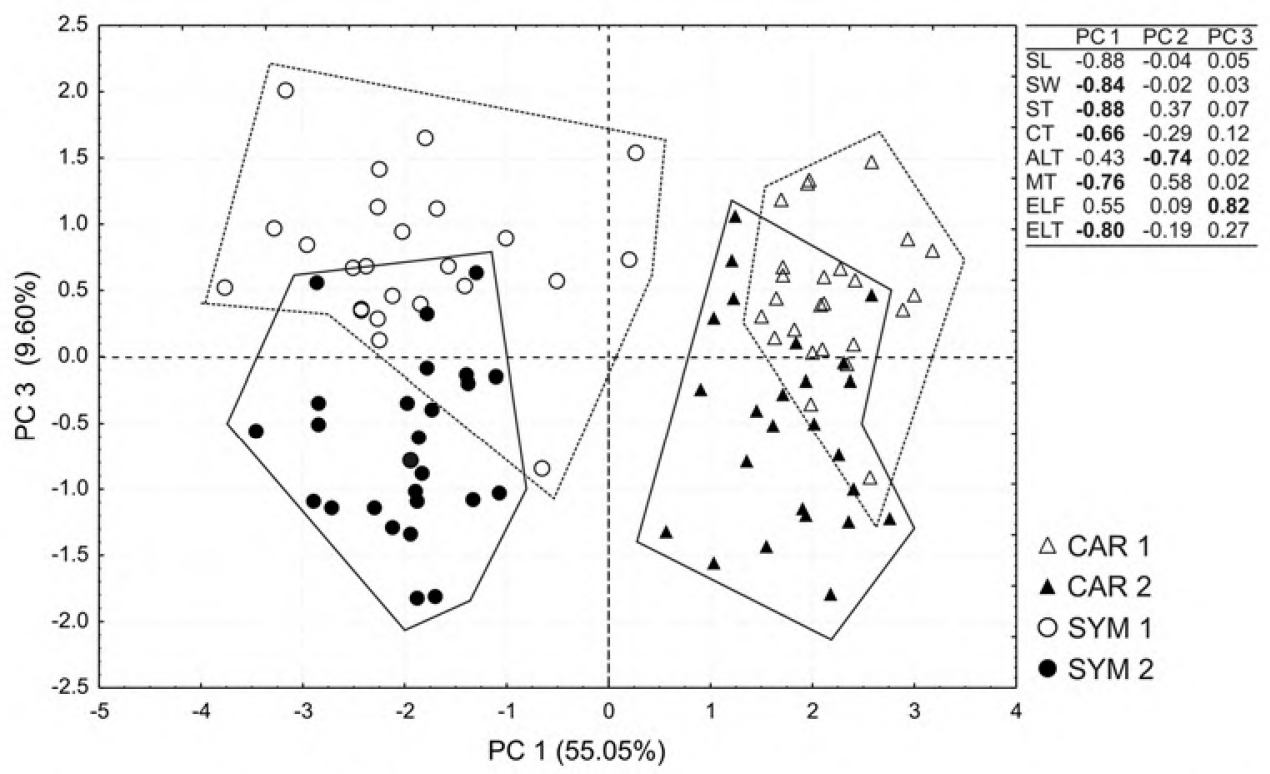

Fig. 1. Scatterplot showing the results of Principal Component Analysis (PCA) of individuals representing particular ecological groups. Factor loadings for all characteristics and variance explained by each axis are provided. The highest values of factor loadings are given in bold ( $>0.60$ ). See Table 1 for habitat descriptions and Material and methods for abbreviations of characteristics. CAR $1-C l a d o n i a$ cariosa, Habitat 1; CAR $2-$ C. cariosa, Habitat 2. SYM 1 - C. symphycarpa, Habitat 1; SYM 2 - C. symphycarpa, Habitat 2. 


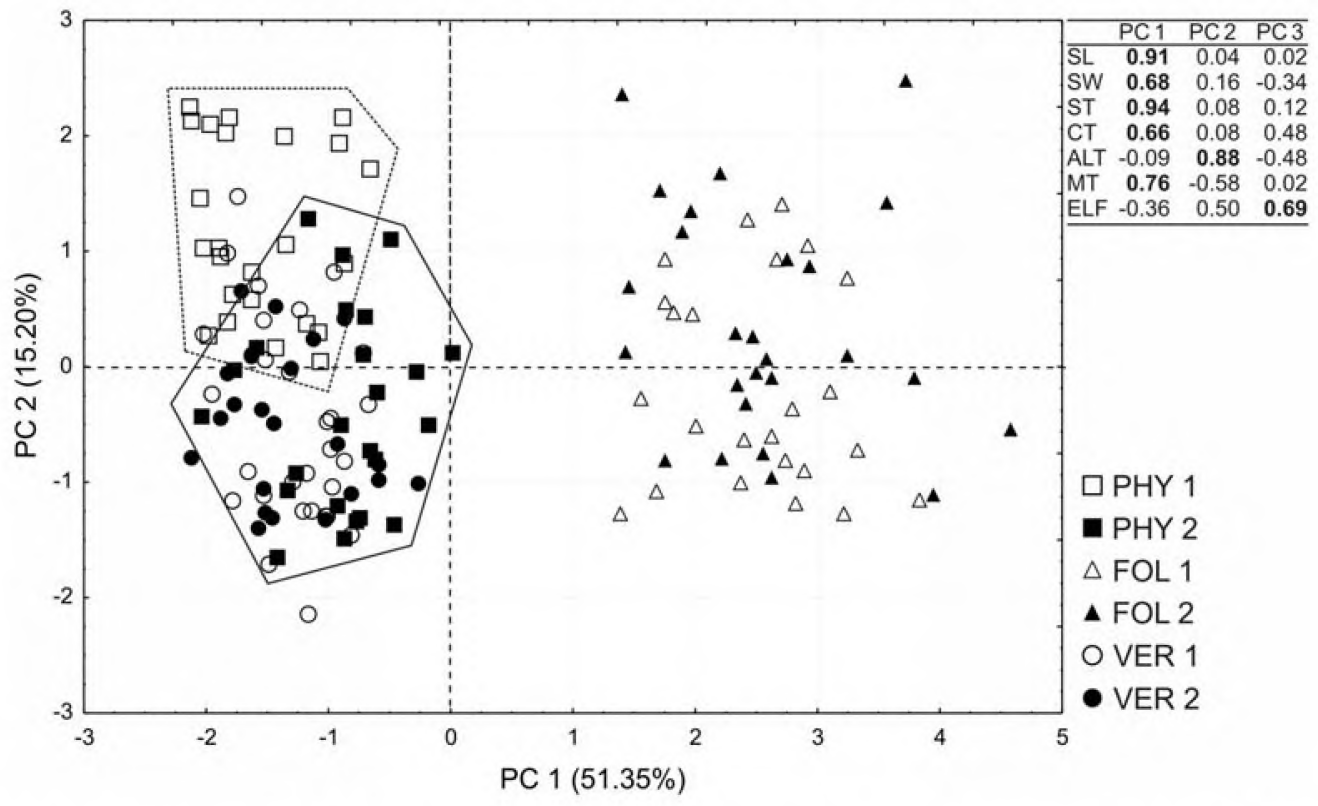

Fig. 2. Scatterplot showing the results of Principal Component Analysis (PCA) of individuals representing particular ecological groups. Factor loadings for all characteristics and variance explained by each axis are provided. The highest values of factor loadings are given in bold $(>0.60)$. See Table 1 for habitat descriptions and Material and methods for abbreviations of characteristics. PHY $1-C l a d o n i a$ phyllophora, Habitat 1; PHY 2 - C. phyllophora, Habitat 2. FOL 1 - C. foliacea, Habitat 1; FOL 2 - C. foliacea, Habitat 2 . VER 1 C. cervicornis subsp. verticillata, Habitat 1; VER $2-$ C. cervicornis subsp. verticillata, Habitat 2.

gular species. The squamule width and overall squamule thickness are always relatively stable for the taxa, regardless of the habitat. Considering the intraspecific variability, primary squamules of Cladonia phyllophora and $C$. foliacea are the most phenotypically dependent upon habitat factors.

According to the PCA performed on matrix 1, and considering the features modified by the microhabitat, a third axis separates the two habitat groups of both species. This axis is influenced mostly by the frequency of the epinecral layer (Fig. 1). The analysis based on data from matrix 2 demonstrates a clear distinction between the two habitat groups only in the case of Cladonia phyllophora. Five features (SL, SW, ST, CT, NT) were the most important for separation along the first axis and the algal layer along the second one. The habitat groups of the other species are not so differentiated (Fig. 2).

Generally, a full range of cortical surface rugosity, from entirely smooth, through slightly rugose, to strongly fissured and cracked, was observed under SEM in all the considered species. It is important to note that this ultrasculpture diversity relates to the squamules originating from the singular sample (Figs 3-7). None-specific patterns of squamule ultrasculpture were recognised, which could correlate with the habitat. In some cases, high variability of the cortex surface was even observed within one squamule (Figs $4 \mathrm{c}$ and $7 \mathrm{e}$ ).

\section{Discussion}

The huge modificatory variability of many lichens allows them to adapt to diverse environmental conditions and to colonise various habitats. Microclimatic factors

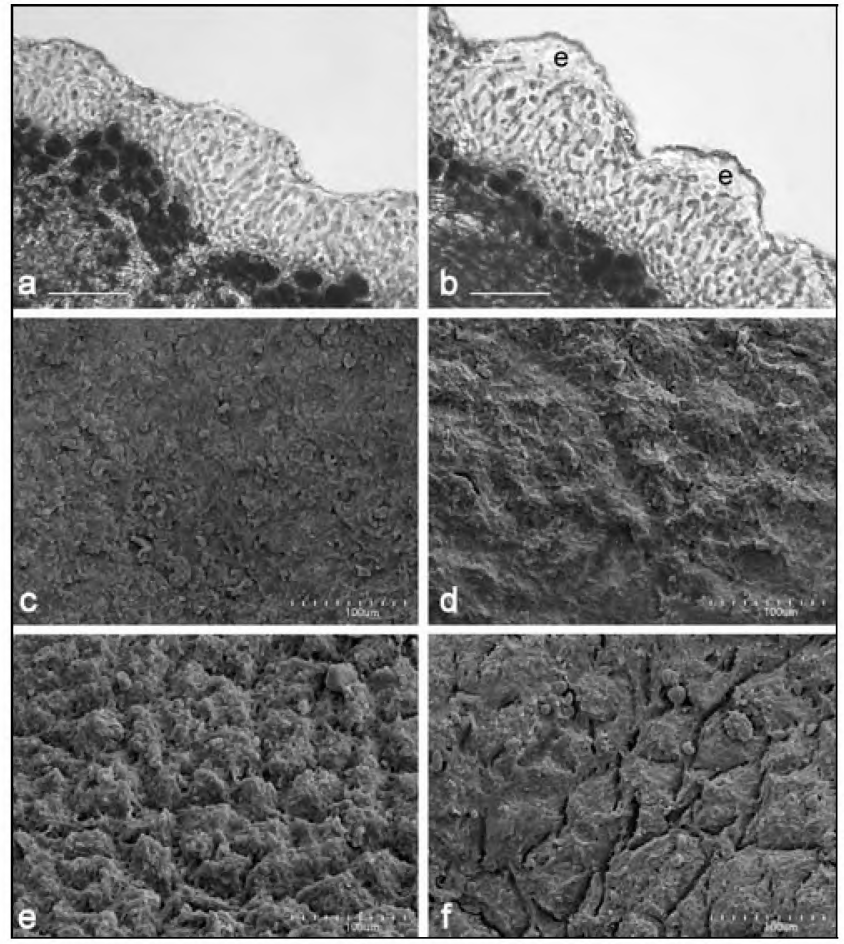

Fig. 3. Cladonia cariosa - sample from Site 1, Habitat 2; a, $\mathrm{b}$ : transverse sections of primary squamule, scale $=40 \mu \mathrm{m}$ (e - epinecral layer). c-f: range of the primary thallus surface ulrasculpture, SEM micrographs, scale $=100 \mu \mathrm{m}$.

may modify and even affect the development of some features, both morphological and anatomical. Different eco-morphological populations for the lichen species were observed and correlated with their specific habitat (e.g. Tretiach \& Brown 1995; Pintado et al. 1997; Rikki- 


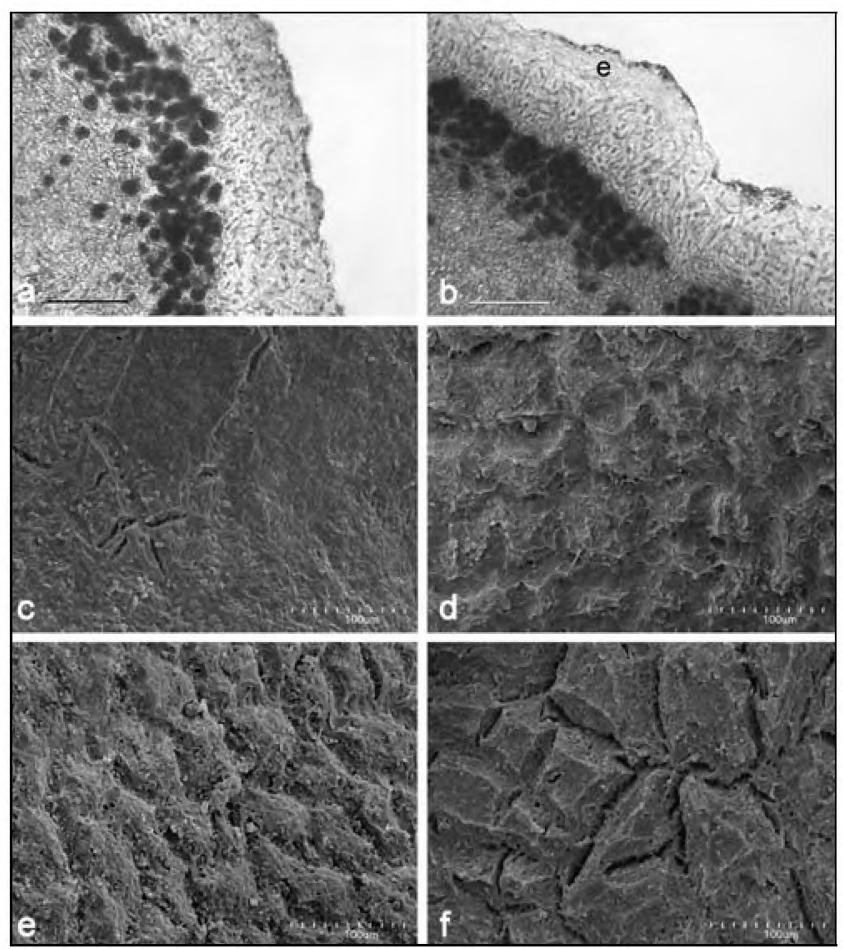

Fig. 4. Cladonia symphycarpa - sample from Site 2, Habitat 1; $\mathrm{a}$, b: transverse sections of primary squamule, scale $=50 \mu \mathrm{m}$ (e - epinecral layer). c-f: range of the primary thallus surface ulrasculpture, SEM micrographs, scale $=100 \mu \mathrm{m}$.
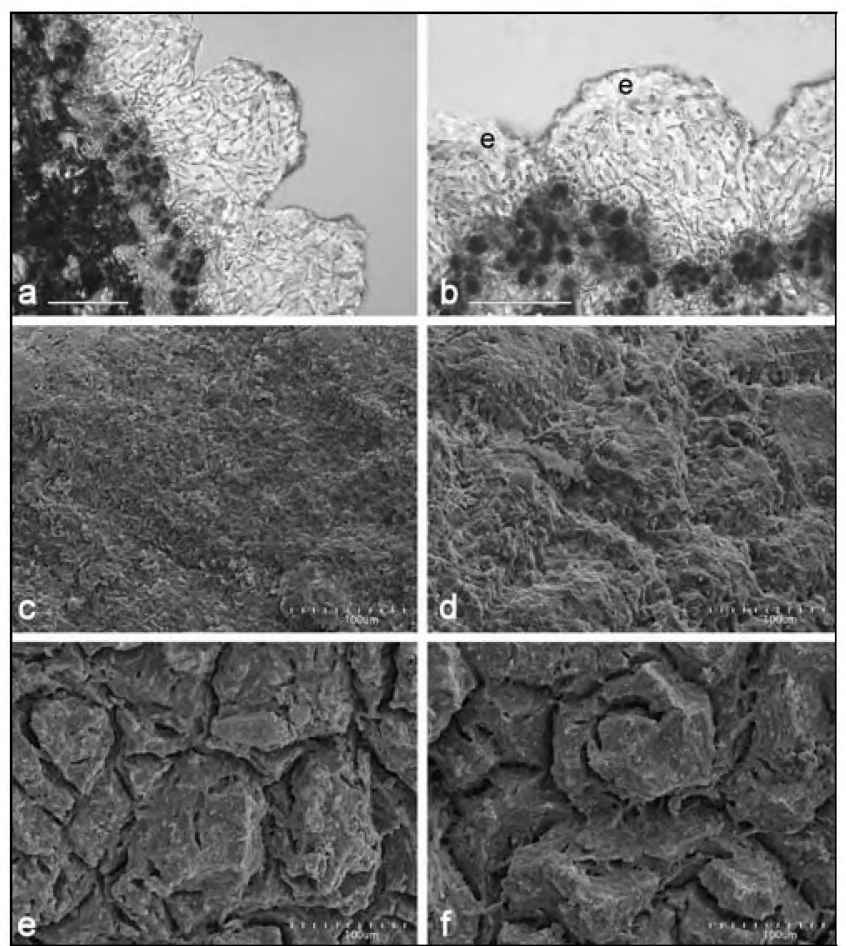

Fig. 5. Cladonia foliacea - sample from Site 2, Habitat 1; a, $\mathrm{b}$ : transverse sections of primary squamule, scale $=50 \mu \mathrm{m}(\mathrm{e}-$ epinecral layer). $\mathbf{c}-\mathrm{f}$ : range of the primary thallus surface ulrasculpture, SEM micrographs, scale $=100 \mu \mathrm{m}$.

nen 1997; Büdel \& Scheidegger 2008). Many Cladonia are known for their high morphological diversity, and

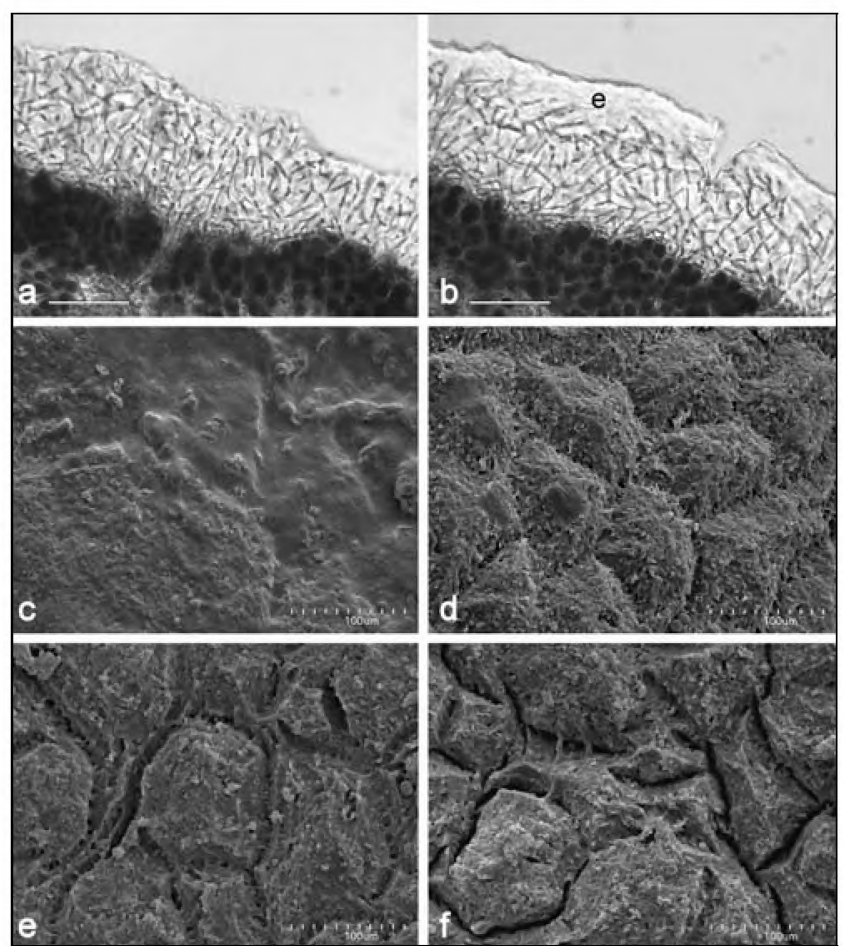

Fig. 6. Cladonia phyllophora - sample from Site 3, Habitat 1; a, b: transverse sections of primary squamule, scale $=40 \mu \mathrm{m}$ (e - epinecral layer). c-f: range of the primary thallus surface ulrasculpture, SEM micrographs, scale $=100 \mu \mathrm{m}$.
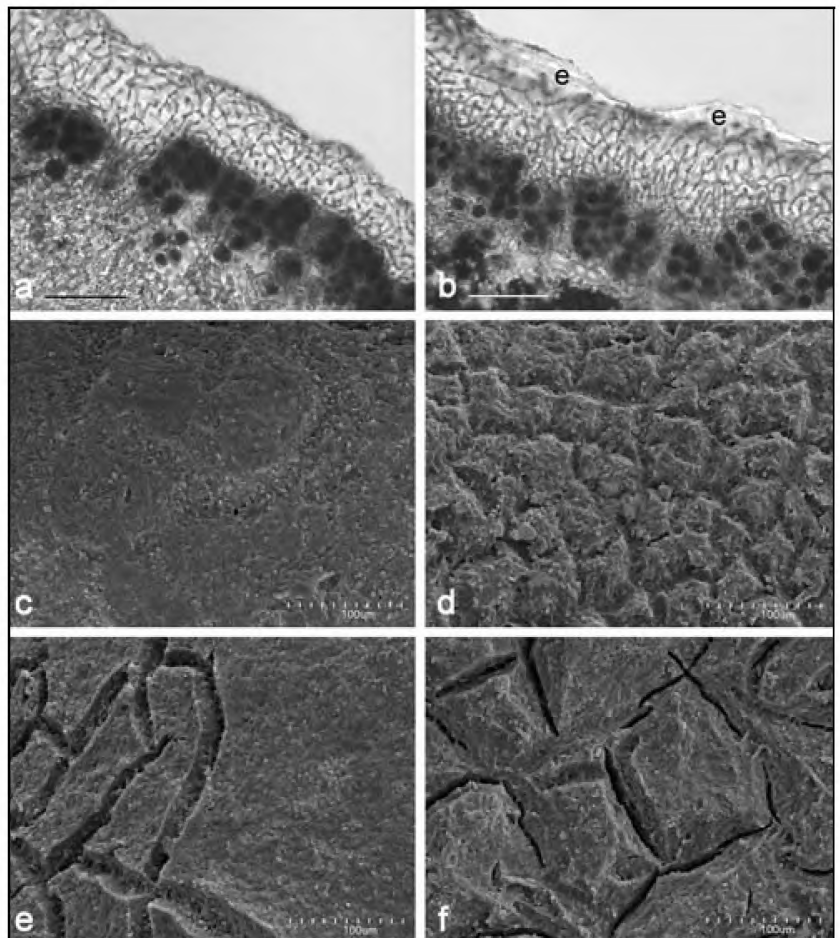

Fig. 7. Cladonia cervicornis subsp. verticillata-sample from Site 3, Habitat $1 ; a, b$ : transverse sections of primary squamule, scale $=40 \mu \mathrm{m}$ (e-epinecral layer). $\mathrm{c}-\mathrm{f}$ : range of the primary thallus surface ulrasculpture, SEM micrographs, scale $=100 \mu \mathrm{m}$.

such plasticity was found to be associated with the influence of environmental factors and/or development 
stage and maturity of individuals (Ahti 2000; Osyczka 2005).

There are aggregates of Cladonia in which the character of primary squamules has been considered as fundamental - or at least important - in related taxa diagnosis, e.g. the C. cariosa, C. cervicornis, C. coniocraea, $C$. digitata, C. foliacea and C. pyxidata groups. Recently, taxonomic problems have tried to be resolved by means of molecular studies (e.g. Kotelko \& PierceyNormore 2010; Pino-Bodas et al. 2010; Pino-Bodas et al. 2011; Pino-Bodas et al. 2012). Some of these papers suggest that the characters are apparently modified by environmental conditions or they can be dependent on the stage of development of individuals. Nevertheless, the plasticity of features is often not taken into account if the obtained monophyletic linkages have to be somehow explained by their phenotypes. In such case, there is a risk that ascertained features are overinterpreted from a taxonomic point of view. Therefore, study on phenotypic plasticity, particularly on the basis on neighbouring populations and those having the same life history, seems to be essential for understanding the sources and ranges of variability.

The main factor differentiating the two types of habitats considered here is their exposure to sunlight and, as a consequence, local daily humidity and temperature fluctuations. Important, mainly anatomical, differences in the organisation of primary squamules between populations from contrasting habitats have been found in our study (Figs 1 and 2). The epinecral layer proved to appear more frequently in the C. cariosa, $C$. symphycarpa and C. phyllophora populations from fully open situations (Table 3). Additionally, we observed that in such places, this layer is more continuous and somewhat thicker. We would assert that the presence of an epinecral layer is an individual feature of the specimen or may even vary within the singular squamule (e.g., Figs 3, 4, 5). Therefore, we cannot confirm the taxonomic value of this feature, as was recently found in the C. cariosa group (Pino-Bodas et al. 2012). In a general context, an upper cortex with an epinecral layer appears in the species, or in some specimens of the same species, which exist in a sunny and fully exposed habitat; the structure serves as a protective function (Büdel \& Lange 1994; Büdel \& Scheidegger 2008). Cladonia foliacea and C. cervicornis subsp. verticillata form an outer epinecral layer sporadically (Figs 5 and 7). However, in sunny populations of both taxa and C. phyllophora, a relatively thicker cortex was noted. One of the functions of this layer is protection of the photobiont against excessive light (Jahns 1988; Kappen 1988). Besides the aforementioned clear anatomical modifications, a thicker algal layer and thicker medulla were observed in shady populations of $C$. foliacea and C. phyllophora, respectively (Table 3 ). However, these correlations are relatively weak (Table 4). Considering the morphology, the squamules proved to be significantly longer for specimens of $C$. foliacea from sunny sites (Table 4). They refer somewhat to intermediate forms between C. convoluta (Lam.) Anders and C. fo-

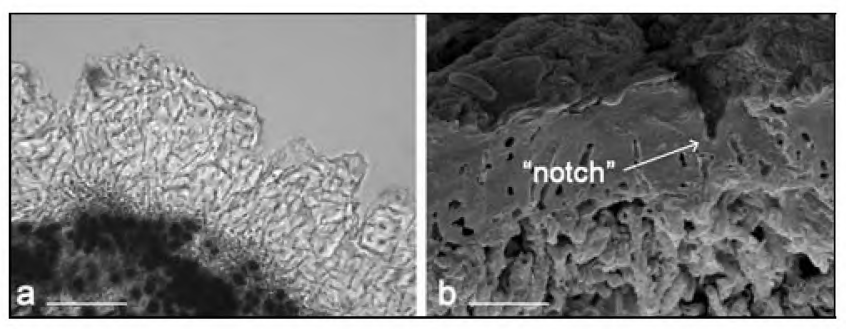

Fig. 8. Fissures and "notches" in the cortical layer of Cladonia foliacea primary squamule - sample from Site 2, Habitat 2; transverse section under light microscope, scale $=40 \mu \mathrm{m}$ (a) and under $\mathrm{SEM}$, scale $=50 \mu \mathrm{m}(\mathrm{b})$.

liacea (Burgaz et al. 1993). According to Pino-Bodas et al. (2010), the molecular and morphological data does not delimit the two species within the C. convoluta/C. foliacea complex. Moreover, morphological diversity was suggested as a phenotypical response to environmental conditions (Litterski \& Ahti 2004; PinoBodas et al. 2010).

Inspection of primary squamules under SEM did not show important differences in the cortex ultrasculpture between populations from different habitats. Furthermore, a full range of cortical surface rugosity within one sample was sometimes observed (Figs 37). Although the taxonomic value of the cortical surface under SEM in the $C$. cariosa group was appointed (Pino-Bodas et al. 2012), our results contradict this thesis. Presumably, fractures on the surface of squamules are connected with physical processes, for example associated with their growth and/or swelling during water absorption. Thus, the sculpture of the cortex can be explained by theories related to the strength of materials (e.g. Schijve 2009). When examining crosssections stained with a lactophenol blue solution and under SEM, fungal hyphae with strongly gelified walls in a number of areas of the cortical layer can be seen (Fig. 8). The pressure arising from the inside of the squamule causes the development of cracks and fissures in a rigid and low elastic cortex. This process can be accelerated by the so-called notch effect (e.g. Pluvinage \& Gjonaj 2001). When the notch radius is smaller, or the end of the notch is sharper, then the stress concentration is higher at this point, and the process of further cracking is more likely (Fig. 8). In addition to these, there are many other processes, e.g. bending, torsion, which could affect the cortex.

Finally, the phenotypic variability of specimens of Cladonia can be heavily induced by environmental factors and growth phases and is not necessarily a reflection of their genotype (Ahti 2000; Kotelko \& Piercey-Normore 2010). Due to this high plasticity, taxonomic evaluation of the significance and usefulness of some features is not possible without taking into account these facts. This particularly concerns continuous features, inherently variable, whose development state could depend on the sum of various factors. 


\section{Acknowledgements}

We would like to thank Dr Danuta Semik (Kraków) and Dr Olga Woźnicka (Kraków) for their technical assistance. We are grateful to Dr Stanistaw Krenich (Kraków) for his guidance on the physical aspect of the tensile strength of materials. We are also indebted to the anonymous Reviewer for valuable comments on earlier draft of this paper. The study was partially supported by the Faculty of Biology and Earth Sciences, Jagiellonian University (subvention No K/DSC/000815).

\section{References}

Ahti T. 2000. Cladoniaceae. Flora Neotropica Monograph 78: 1362.

Ahti T. \& Hammer S. 2002. Cladonia, pp. 131-158. In: Nash III T.H., Ryan B.D., Gries C. \& Bungartz F. (eds), Lichen Flora of the Greater Sonoran Desert Region. Vol. I, Lichens Unlimited, Arizona State University, Tempe, Arizona.

Burgaz A.R., Escudero A. \& Ahti T 1993. Morphometric variation in primary squamules of Cladonia foliacea and C. convoluta. Nova Hedwigia 57: 231-238.

Büdel B. \& Lange O.L. 1994. The role of cortical and epinecral layers in the lichen genus Peltula. Cryptog. Bot. 4: 262-269.

Büdel B. \& Scheidegger C. 2008. Thallus morphology and anatomy, pp. 40-68. In: Nash III T.H. (eds), Lichen Biology. Second Edition. Cambridge University Press, Cambridge.

Dolnik C., Beck A. \& Zarabska D. 2010. Distinction of Cladonia rei and C. subulata based on molecular, chemical and morphological characteristics. Lichenologist 42: 373-386.

Jahns H.M. 1988. The establishment, individuality and growth of lichen thalli. Biol. J. Linnean Soc. 96: 21-29.

James P.W. 2009. Cladonia P. Browne (1756), pp. 309-338. In: Smith C.W., Aptroot A., Coppins B.J., Fletcher A., Gilbert O.L., James P.W. \& Wolseley P.A. (eds), The lichens of Great Britain and Ireland. British Lichen Society, London.

Kappen L. 1988. Ecophysiological relationships in different climatic regions, pp. 37-100. In: Galun M. (eds), CRC Handbook of Lichenology, Volume II. CRC Press, Boca Raton.

Kotelko R. \& Piercey-Normore M.D. 2010. Cladonia pyxidata and C. pocillum; genetic evidence to regard them as conspecific. Mycologia 102: 534-545.

Litterski B. \& Ahti T. 2004. World distribution of selected European Cladonia species. Symb. Bot. Upsal. 34: 205-236.

MycoBank 2012. Fungal Databases Nomenclature and Species Banks. http://www.mycobank.org. Accessed 24 April 2012
Orange A., James P.W. \& White F.J. 2001. Microchemical methods for the identification of lichens. British Lichen Society, London, $101 \mathrm{pp}$.

Osyczka P. 2005. Note about new and rarely recorded taxa of the genus Cladonia from the Arctic island Spitsbergen (Svalbard). Acta Soc. Bot. Pol. 74: 243-246.

Osyczka P. 2011. The genus Cladonia, group Cocciferae, in Poland. Herzogia 24: 209-227.

Osyczka P. 2012. The lichens of Cladonia, 'supergroup' Perviae, in Poland. Herzogia 25: 15-30.

Osyczka P. \& Skubała K. 2011. Chemical races of Cladonia cariosa and C. symphycarpa (lichenized Ascomycota) - a Polish case study in a worldwide context. Nova Hedwigia 93: 363373.

Osyczka P., Flakus A., Węgrzyn M. \& Cykowska B. 2007. Cladonia crispata var. cetrarifformis (Cladoniaceae, lichenized Ascomycota) in the Tatra Mts. Biologia 62: 144-147.

Pino-Bodas R., Martín M.P. \& Burgaz A.R. 2010. Insight into the Cladonia convoluta-C. foliacea (Cladoniaceae, Ascomycota) complex and related species, revealed through morphological, biochemical and phylogenetic analyses. Syst. Biodivers. 8: $575-586$.

Pino-Bodas R., Burgaz A.R., Martín M.P. \& Lumbsch H.T. 2011. Phenotypical plasticity and homoplasy complicate species delimitation in the Cladonia gracilis group (Cladoniaceae, Ascomycota). Org. Divers. Evol. 11: 343-355.

Pino-Bodas R., Burgaz A.R., Martín M.P. \& Lumbsch H.T. 2012. Species delimitations in the Cladonia cariosa group (Cladoniaceae, Ascomycota). Lichenologist 44: 121-135.

Pintado A., Valladares F. \& Sancho L.G. 1997. Exploring phenotypic plasticity in the lichen Ramalina capitata: morphology, water relations and chlorophyll content in north- and southfacing polulations. Ann. Botany 80: 345-353

Pluvinage G. \& Gjonaj M. 2001. Notch effects in fatigue and fracture. Kluwer Academic Publishers, Dordrecht, 361 pp.

Rikkinen J. 1997. Habitat shifts and morphological variation of Pseudevernia furfuracea along a topographical gradient, pp. 223-245. In: Tibell L. \& Hedberg I. (eds), Lichen Studies Dedicated to Rolf Santesson. Symbolae Botanicae Upsalienses, Acta Universitatis Upsaliensis, Uppsala.

Schijve J. 2009. Fatigue of structures and materials. Springer, Berlin, 530 pp.

Stenroos S., Hyvönen J., Myllys L., Thell A. \& Ahti T. 2002. Phylogeny of the genus Cladonia s. lat. (Cladoniaceae, Ascomycetes) inferred from molecular, morphological, and chemical data. Cladistics 18: 237-278.

Tretiach M. \& Brown D.H. 1995. Morphological and physiological differences between epilithic and epiphytic populations of the lichen Parmelia pastillifera. Ann. Bot. 75: 627-632 